\title{
Editor's note on changes at the WTR
}

It is with pleasure that I call your attention to the following changes in the team responsible for producing the World Trade Review:

\section{Effective immediately}

- Judith Goldstein, a member of the Political Science Department at Stanford University, has joined the Editorial Board

- Joseph Weiler, a current member of the Editorial Board, has agreed to fill the newly created position of Book Review Editor

Books for review should be sent to:

J. H. H. Weiler, University Professor and Jean Monnet Chair

Director, Global Law School Program, NYU School of Law,

40 Washington Square, NY. NY. 10012

Professor Weiler may be contacted at 〈weiler@jeanmonnetprogram.org〉

- Kevin Klingbeil, New York University School of Law, will fill the new position of Associate Book Review Editor

Effective 1 January 2005

- Douglas A. Irwin, a member of the Economics Department at Dartmouth College, will take over as Editor.

As from 1.1.2005 all correspondence related to the WTR should be addressed to:

Professor Irwin at 〈World.Trade.Review@Dartmouth.EDU〉

- Richard Blackhurst, the current Editor, will join the Editorial Board 